\title{
Porcine circovirus type 2 upregulates endothelial-derived IL-8 production in porcine iliac artery endothelial cells via the RIG-I/MDA-5/MAVS/JNK signaling pathway
}

Fengyang Shi ${ }^{1+}$, Qiuming $\mathrm{Li}^{1+}$, Shiyu Liu', Fengying Liu', Jianfang Wang ${ }^{2}$, Defeng Cui ${ }^{2}$, Xiaolin Hou ${ }^{1}$, Shuanghai Zhou', Yonghong Zhang ${ }^{1 *}$ and Huanrong $\mathrm{Li}^{1^{*}}$ (D)

\begin{abstract}
Background: Dysfunction of endothelial cells and vascular system is one of the most important pathological changes of porcine circovirus disease (PCVD) caused by porcine circovirus type 2 (PCV2). PCV2-infected endothelial cells can upregulate the production of endothelial-derived IL-8, which can inhibit the maturation of dendritic cells. Endothelial-derived IL-8 has different structural and biological characteristics compared with monocyte-derived IL-8. However, the mechanism of endothelial-derived IL-8 production is still unclear.

Results: Key molecules of RIG-I-like signaling pathway RIG-I, MDA-5, MAVS and a key molecule of JNK signaling pathway c-Jun in PCV2-infected porcine iliac artery endothelial cells (PIECs) were upregulated significantly detected with quantitative PCR, Western blot and fluorescence confocal microscopy, while no significant changes were found in NF-KB signaling pathway. Meanwhile, the expression of endothelial-derived IL-8 was downregulated after RIG-I, MDA-5, or MAVS genes in PIECs were knocked down and PIECs were treated by JNK inhibitor.

Conclusions: PCV2 can activate RIG-I/MDA-5/MAVS/JNK signaling pathway to induce the production of endothelialderived IL-8 in PIECS, which provides an insight into the further study of endothelial dysfunction and vascular system disorder caused by PCV2.
\end{abstract}

Keywords: Porcine circovirus type 2, Endothelium-derived IL-8, Porcine iliac artery endothelial cells, RIG-I-like signaling pathway, JNK signaling pathway

\section{Background}

Porcine circovirus type 2 (PCV2) is a major pathogen associated with postweaning multisystemic wasting syndrome (PMWS), which is characterized by lymphocyte apoptosis and inflammatory cell infiltration [1]. In addition, endothelial cell disfunction and vascular system disorders are also the main symptoms of porcine

\footnotetext{
*Correspondence: yhh2266@126.com; lihuanrong1@126.com

${ }^{\dagger}$ Fengyang Shi and Qiuming Li contributed equally to this work.

${ }^{1}$ College of Animal Science and Technology, Beijing University of Agriculture, No. 7 Beinong Road, Beijing 102206, Changping District, China

Full list of author information is available at the end of the article
}

circovirus disease (PCVD) [2]. The PCV2-infected endothelial cells can regulate leukocyte migration, inflammatory responses [3] and induce the production of endothelial-derived IL-8 [4]. It is reported that endothelial-derived IL-8, with a pentapeptide AVLPR extension at the NH2-terminus [5], has different biological function compared with monocyte-derived IL-8 [6]. Our previous reports also showed that the endothelial IL-8 upregulated by PCV2 infection could inhibit the maturation and antigen presentation of dendritic cells $[4,7]$.

C C The Author(s). 2020 Open Access This article is licensed under a Creative Commons Attribution 4.0 International License, which permits use, sharing, adaptation, distribution and reproduction in any medium or format, as long as you give appropriate credit to the original author(s) and the source, provide a link to the Creative Commons licence, and indicate if changes were made. The images or other third party material in this article are included in the article's Creative Commons licence, unless indicated otherwise in a credit line to the material. If material is not included in the article's Creative Commons licence and your intended use is not permitted by statutory regulation or exceeds the permitted use, you will need to obtain permission directly from the copyright holder. To view a copy of this licence, visit http://creativecommons.org/licenses/by/4.0/ The Creative Commons Public Domain Dedication waiver (http://creativecommons.org/publicdomain/zero/1.0/) applies to the data made available in this article, unless otherwise stated in a credit line to the data. 
Epithelial IL-8 can be induced by parainfluenza virus type 1 via phosphorylation (p38) of the mitogenactivated protein kinase (p38-MAPKs) signaling pathway [8]. Monocyte-derived IL-8 can be induced by PCV2 via the TLR2/MyD88/NF- $k$ B signaling pathway in porcine alveolar macrophages [9]. Some cytokines can be induced by pattern recognition receptors (PRRs), such as retinoic acid-inducible gene I (RIG-I) and melanoma differentiation-associated gene-5 (MDA-5) [10, 11], which can recruit downstream molecules (NF-kB, ERK, JNK, or PI3K-Akt) by binding to mitochondrial antiviral signaling protein (MAVS) [12-14]. It is reported that PCV2 can induce IFN- $\beta$ production via the RIG-1/ MDA-5/MAVS/IRF signaling pathway in PK-15 cell [15]. Classical swine fever virus can induce the production of IL- 8 and other proinflammatory cytokines via the RIG-I/MDA-5 pathway $[16,17]$. But whether the mechanism of endothelial-derived IL-8 production is consistent to that of other cell-derived IL-8 is still unknown.

Here, the study focused on the signal pathway of endothelial-derived IL-8 production in PIECs, providing a basis for the further study of endothelial dysfunction and vascular system disorder caused by PCV2.

\section{Results}

PCV2 induces RIG-I, MDA-5 and MAVS activation in PIECs

In order to investigate whether PCV2 could activate the RIG-I-like signaling pathway in PIECs, qPCR was employed to measure the expression levels of RIG-I, MDA-5 and MAVS mRNA. Polyriboinsine-polyribocyaidylic acid (Poly(I:C), which could activate RIG-I and MDA-5 to produce IL-8 in mesothelial cells [18] and some epithelial cells [19], was used as the positive control in this study. The expression levels of RIG-I, MDA-5 and MAVS mRNA in PCV2-PIECs group were higher than those in the PIECs group at 12 and $24 \mathrm{~h}$ post-infection (hpi) $(P<0.05)$ (Fig. 1a, b, c) while substantially increased at $24 \mathrm{hpi}(P<0.01)$. Western blot showed that the protein expression levels of RIG-I, MDA-5 and MAVS were significantly upregulated in PCV2-PIECs group compared with the PIECs group $(P<$ 0.01) (Fig. 1d and Fig. 2). All results above indicated that the RIG-I-like signaling pathway was activated after PCV2 infection.

PCV2 does not activate NF-KB signaling pathway in PIECs In addition to RIG-I-like signaling pathway, NF- $\mathrm{kB}$ signaling pathway also plays an important role in the production of inflammatory-related factors. Based on the previous results [9], we chose to test whether NF- $\mathrm{kB}$ signaling pathway was activated in PIECs following PCV2 infection. The qPCR results showed that the mRNA ex-

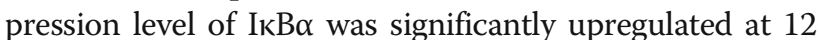
and $24 \mathrm{hpi}$ in PCV2-PIECs group $(P<0.01)$ (Fig. 3a). Western blot showed that the protein expression level of
IкB $\alpha$ was also upregulated in PCV2-PIECs group (Fig. 1d and Fig. 3b). But the expressions of NF- $k B$ p65 and NF- $k B$ p-p65 had no significant changes $(P>0.05)$ (Fig. $1 \mathrm{~d}$ and Fig. 3c, d, e). Fluorescence confocal microscopy further confirmed that there was no significant nuclear translocation of NF-kB in PIECs (Fig. 4), suggesting that NF- $\mathrm{kB}$ was not activated. All results above indicated that PCV2 did not activate NF-KB signaling pathway in PIECs.

\section{PCV2 activates JNK signaling pathway in PIECs}

JNK signaling pathway is an important part of MAPK pathway, which plays an important role in cell cycle, reproduction, apoptosis and cell stress. Based on our microarray results (unpublished data), whether JNK signaling pathway could be activated in PIECs infected with PCV2 were investigated. The mRNA expression levels of c-Jun in the PCV2-PIECs at two time points were both higher than those in the PIECs group $(P<0.05)($ Fig. $5 \mathrm{a})$. The protein levels of JNK and c-Jun in the PCV2-PIECs group were both higher than those in the PIECs group at $24 \mathrm{hpi}(P<$ 0.05 ) (Fig. 1d and Fig. 5b, c). In the fluorescence confocal experiment, a significant nuclear translocation of c-Jun in the PCV2-PIECs group was observed as compared to the control group (Fig. 6). All indicated that JNK signaling pathway in PIECs was activated after PCV2 infection.

\section{RIG-I/MDA-5/MAVS is involved in the upregulation of} endothelial-derived IL-8 expression induced by PCV2 in PIECs

To study the role of RIG-I/MDA-5/MAVS in the production of endothelial-derived IL-8 induced by PCV2, siRNA was designed to knockdown the expression of RIG-I, MDA-5 or MAVS. The expression levels of endothelial-derived IL-8 mRNA and protein in the PCV2-siRIG-I group were significantly downregulated compared to those in the PCV2-PIECs group $(P<0.01)$ (Fig. 7). Similar results were also obtained in the PCV2siMDA-5 and the PCV2-siMAVS groups (Fig. 7). These results strongly suggested that the RIG-I/MDA-5/MAVS pathway was involved in the upregulation of endothelialderived IL-8 expression induced by PCV2 in PIECs.

JNK signaling pathway contributes to the upregulation of endothelial-derived IL-8 expression induced by PCV2 in PIECs

To determine whether the expression of endothelialderived IL- 8 induced by PCV2 was regulated by JNK signaling pathway, a JNK inhibitor was used to treat PIECs. The expression level of endothelial-derived IL-8 in the inhibitor treatment group was significantly downregulated compared to the control group $(P<0.01)$ (Fig. 8). It suggested that JNK pathway contributed to the upregulation of endothelial-derived IL-8 expression induced by PCV2 in PIECs. 


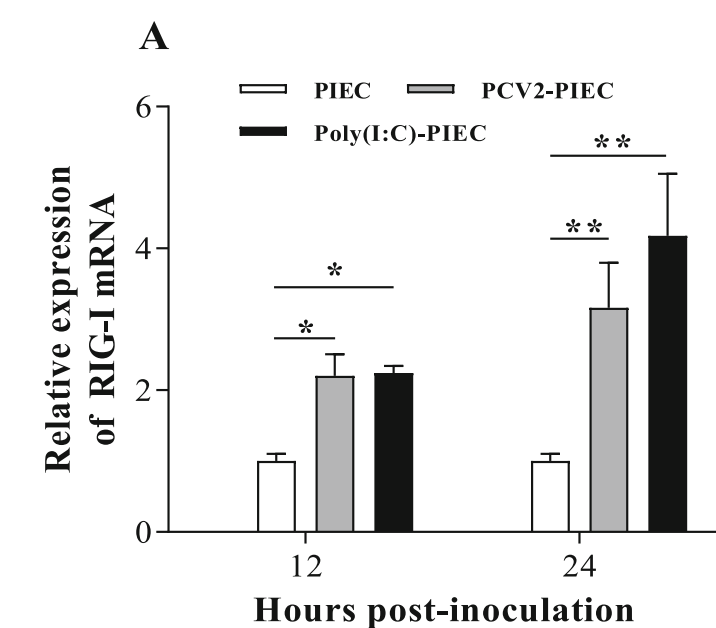

D
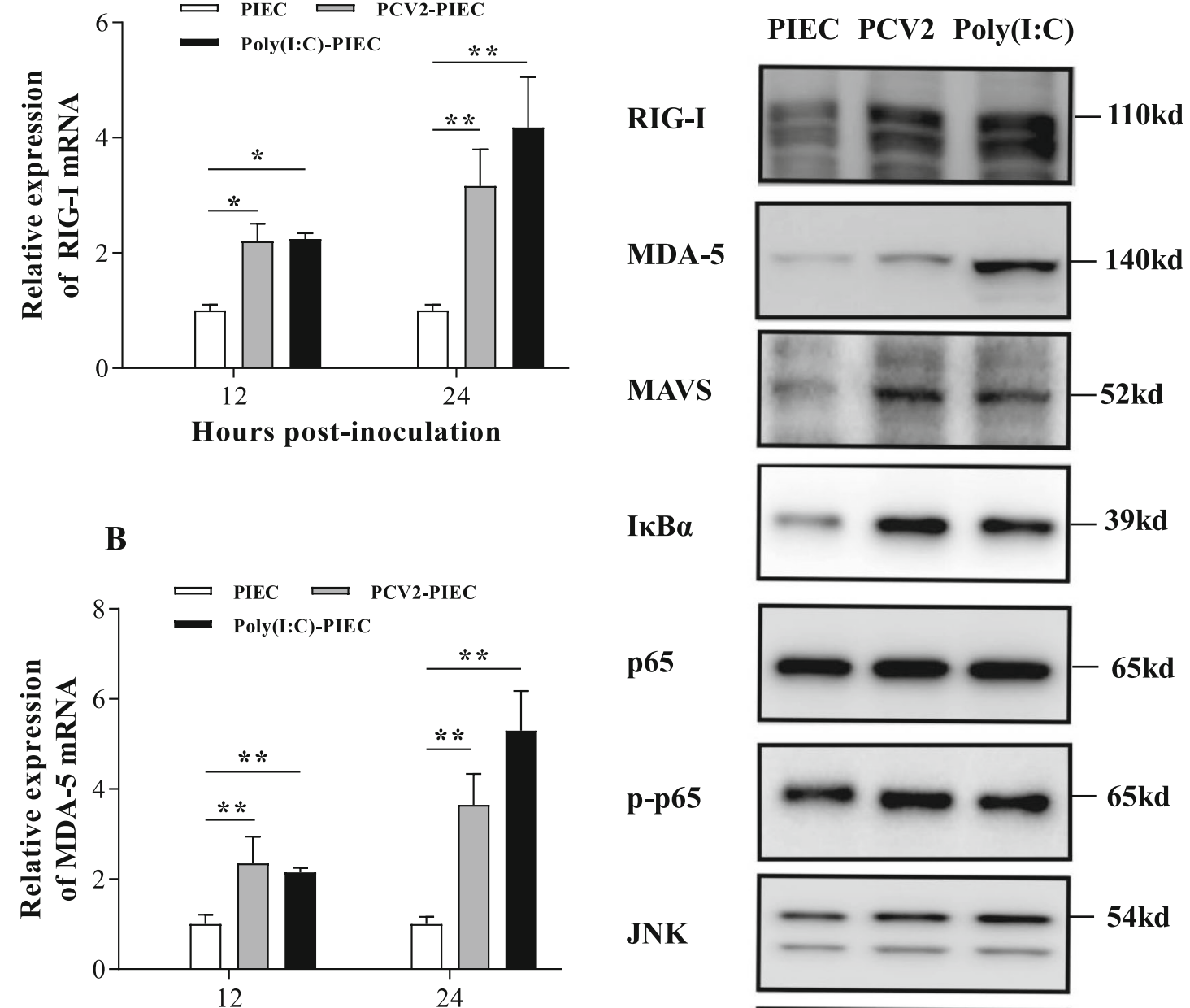

$\mathbf{I} \mathbf{B} \alpha$

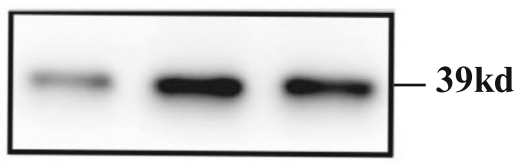

p65

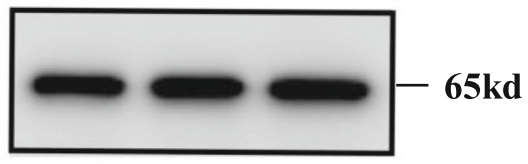

p-p65

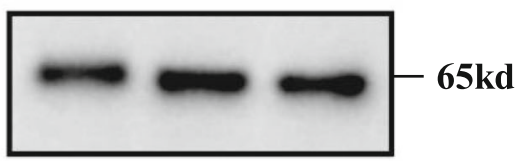

JNK

Hours post-inoculation

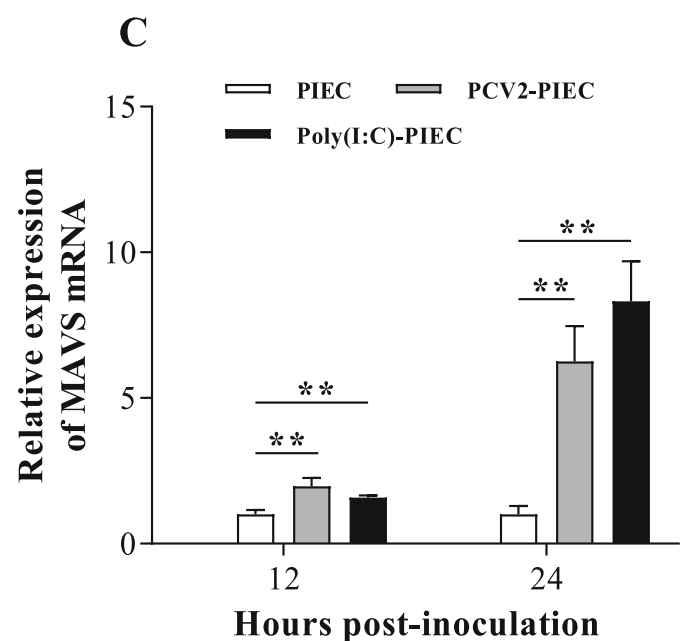

$\beta$-actin

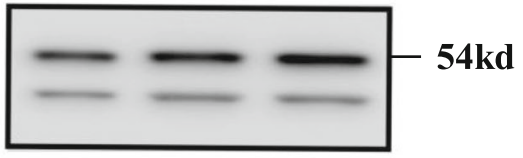

c-Jun
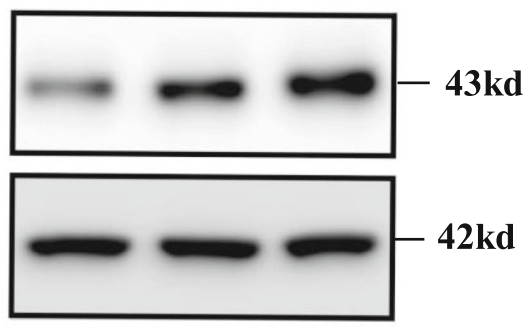

Fig. 1 (See legend on next page.) 
(See figure on previous page.)

Fig. 1 The RIG-I, MDA-5, and MAVS mRNA expression levels induced by PCV2 and the changes of all related protein expression after PCV2 infection in PIECs. PIECs were infected with PCV2 $(\mathrm{MOI}=0.5)$ for $1 \mathrm{~h}$ and then cultured for 12 and $24 \mathrm{~h}$. The levels of RIG-I (a), MDA-5 (b) and MAVS (c) mRNA expression levels were assessed by qPCR. The uninfected PIEC was used as a negative control and Poly(l:C) treatment was used as a positive control. The data are results of three independent experiments of relative expression values compared with $\beta$-actin $m R N A$, and represented as the mean and standard deviation (error bars) for each group. ${ }^{*}, P<0.05 .{ }^{* *}, P<0.01$. PIECs were collected after $P C V 2(\mathrm{MOI}=0.5)$ infection for $24 \mathrm{~h}$. Cell lysates were examined by Western blot with anti-RIG-I, anti-MDA-5, anti-MAVS, anti-IKBa, anti-NF-KB p65, anti-NF-KB p-p65, anti-JNK and anti-c-Jun antibodies (d). The uninfected PIEC was used as a negative control, Poly(l:C) treatment was used as a positive control and endogenous $\beta$-actin expression was used as an internal control

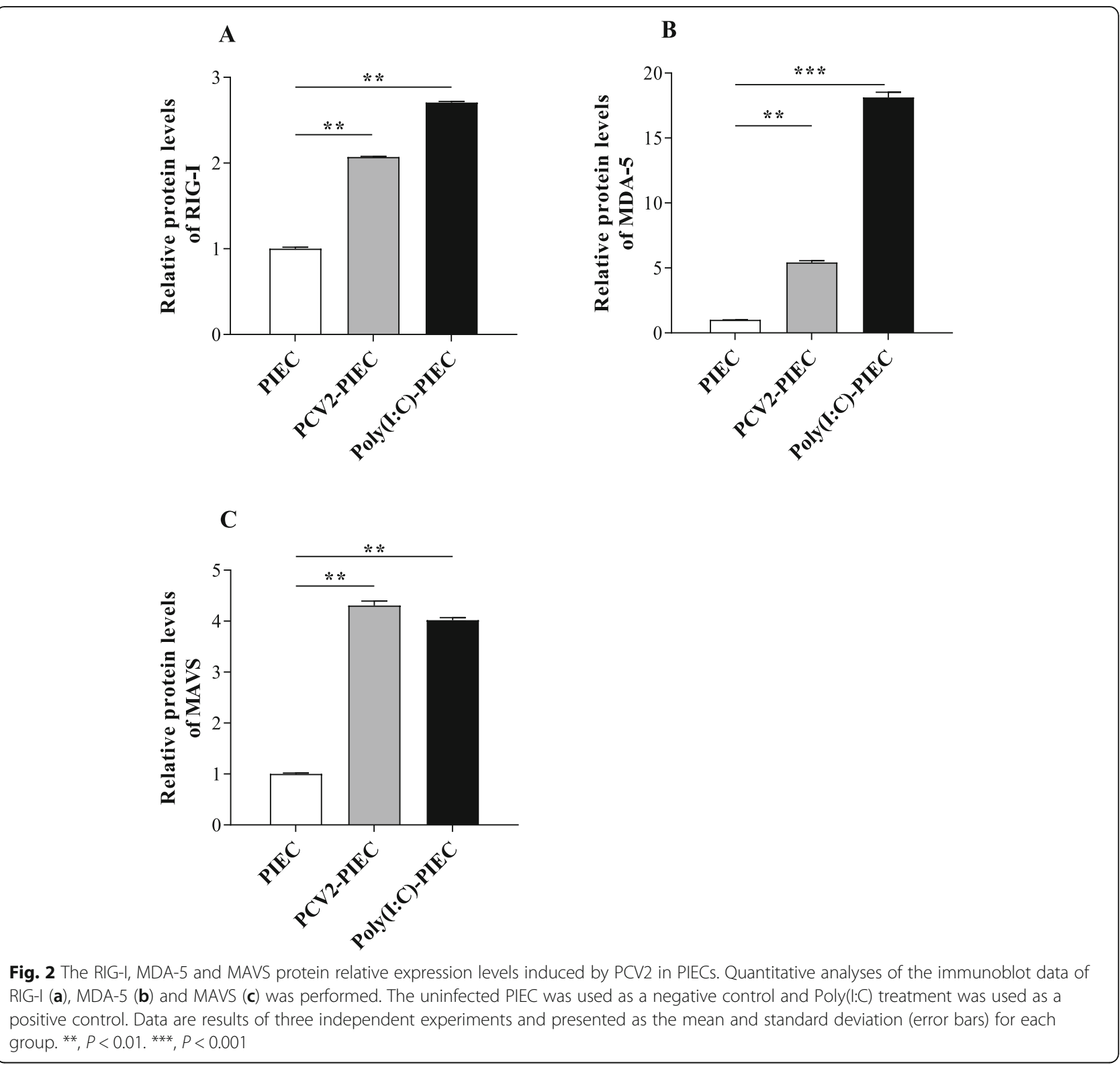



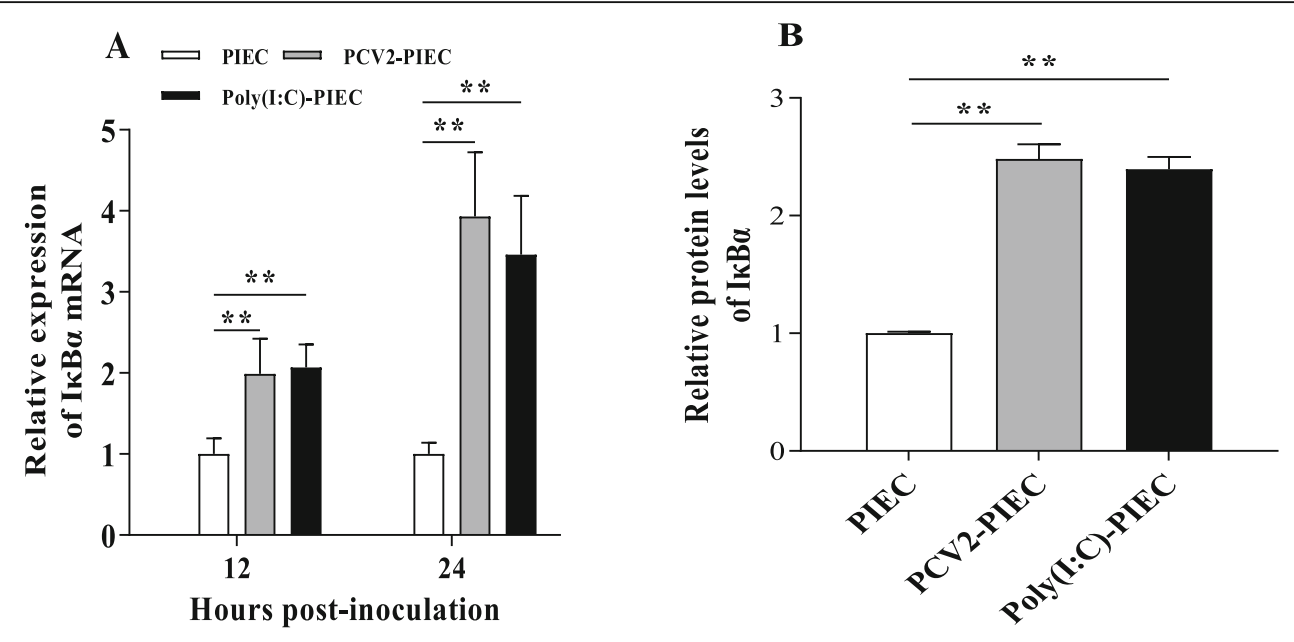

C

D
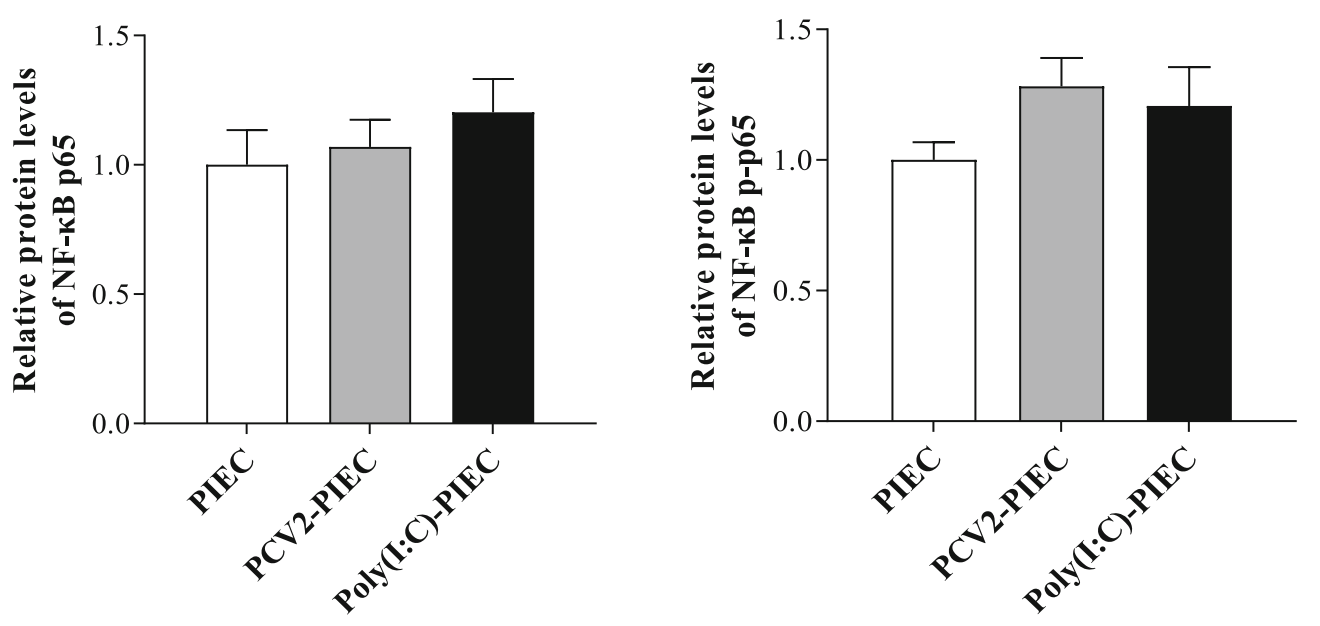

$\mathbf{E}$

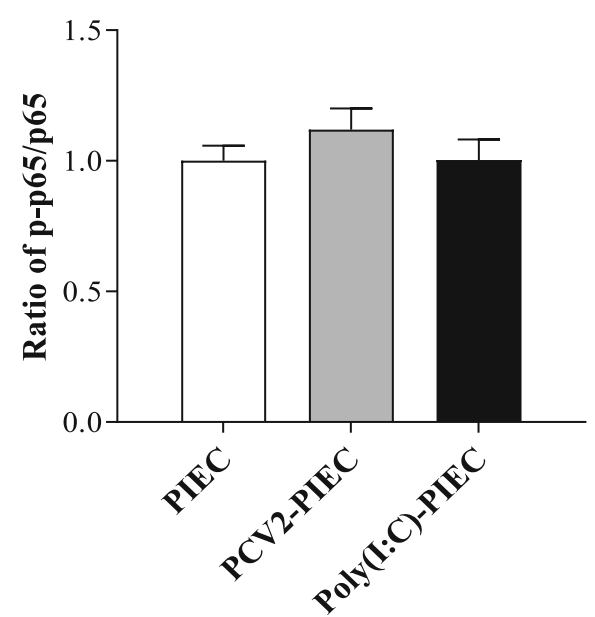

Fig. 3 (See legend on next page.) 
(See figure on previous page.)

Fig. 3 The relative expression levels of key proteins in NF-KB signaling pathway. PIECs were infected with PCV2 (MOI $=0.5)$ for $1 \mathrm{~h}$ and then cultured for 12 and $24 \mathrm{~h}$. The IKBa mRNA expression was assessed by qPCR at two time points (a). Quantitative analyses of the immunoblot data of IKBa (b), NF-KB p65 (c) and NF-KB p-p65 (d) was performed at 24 h. The ratio of NF-KB p-p65/ NF-KB p65 (e). The uninfected PIEC was used as a negative control and Poly $(I: C)$ treatment was used as a positive control. Data are results of three independent experiments and presented as the mean and standard deviation (error bars) for each group. ${ }^{*}, P<0.01$

\section{Discussion}

RIG-I and MDA-5, the sensory molecules of viral infection $[20,21]$, can recognize RNA viruses and some DNA viruses by RNA polymerase III [22] and induce the production of different cytokines by identifying exogenous viral molecules [21, 23]. RIG-I mainly recognizes Paramyxoviridae (Newcasthe Disease Virus, Sendai Virus, and Respiratory Syncytial Virus) [20], Flavivirus [24] and Rhabdoviridae (Rabies Virus) [25]. MDA-5 mainly recognizes Coronaviridae (Mouse Hepatitis Virus) [26]. RIG-I and MDA-5 can simultaneously recognize Measles Virus [27] and West Nile Virus [28]. In both VR1BL and PK-15 cells, RIG-I and MDA-5 also recognize PCV2 together $[15,29]$, which was similar to that of our study in PIECs. All these indicated that PCV2 could infect different kinds of cells in piglets via RIG-I/MDA-5 pathway.

MAVS, which is located on the outer membrane of mitochondria, is a key common adaptor of retinoic acidinduced gene I-like receptors (RLRs) [30]. Caspase recruitment domains (CARDs) are released from the signal suppression state and recruit MAVS by CARD-CARD interaction after RIG-I and MDA-5 identify the viral components in the cytoplasm [31-33]. The activation of MAVS can effectively promote the downstream signaling pathway and induce the productions of interferon and proinflammatory factor [34]. Once MAVS is degraded,

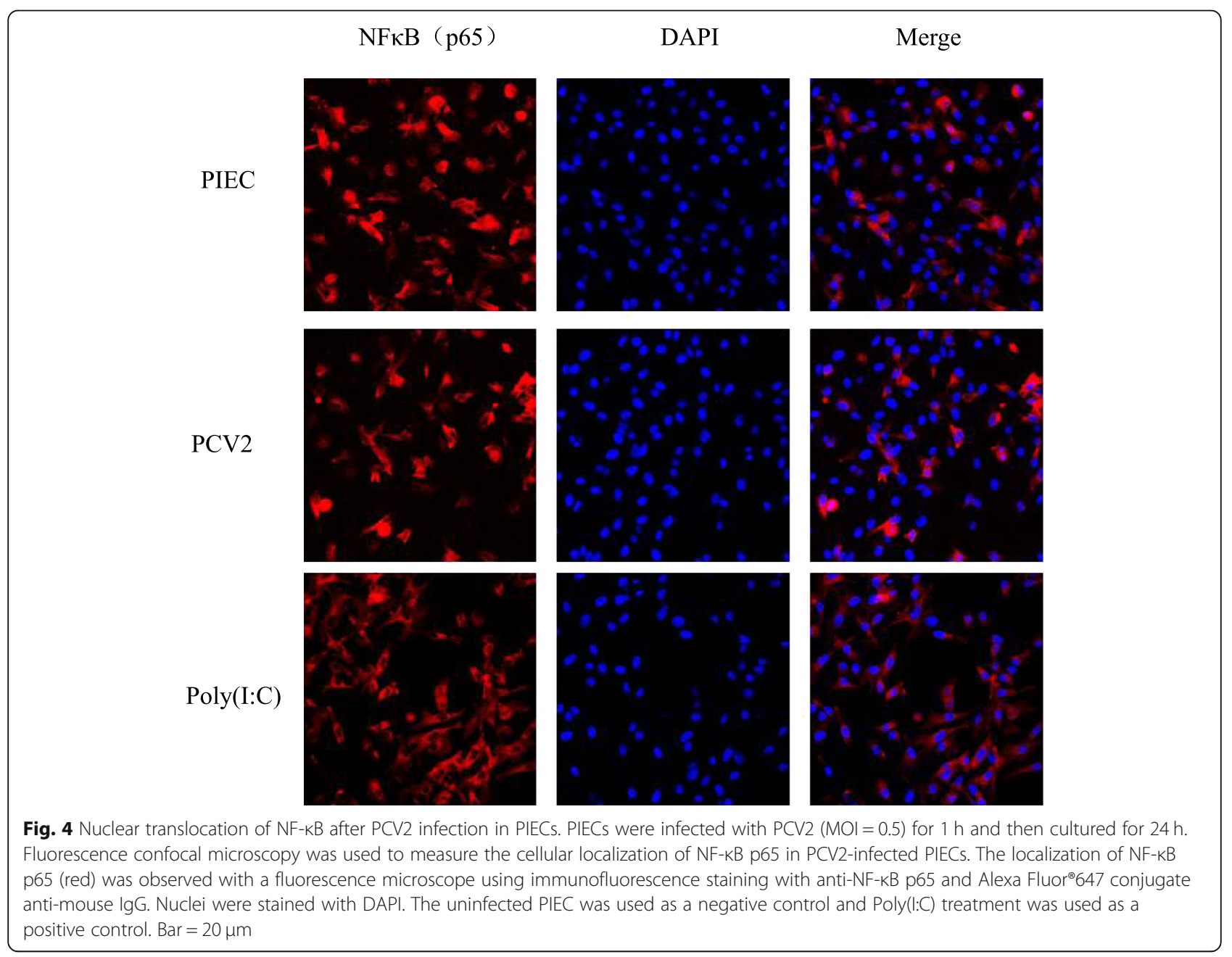




\section{A}

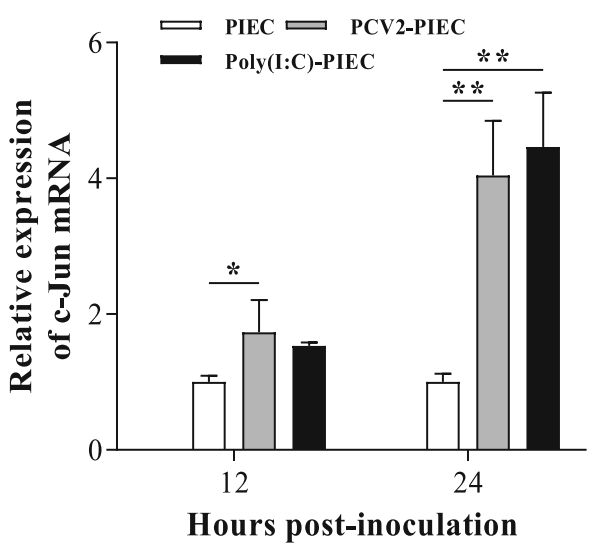

B

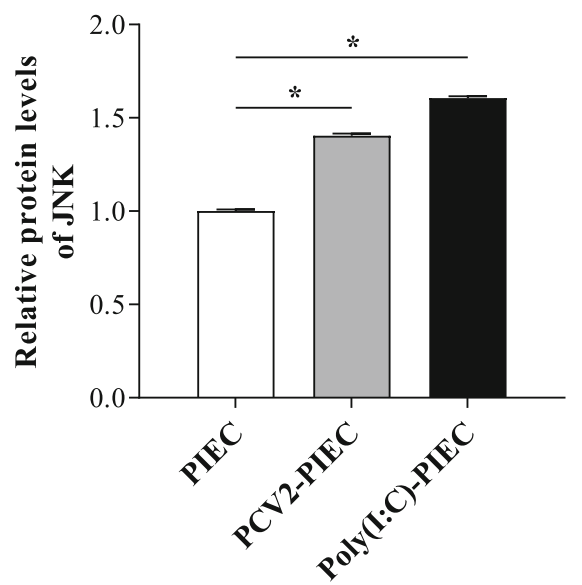

C

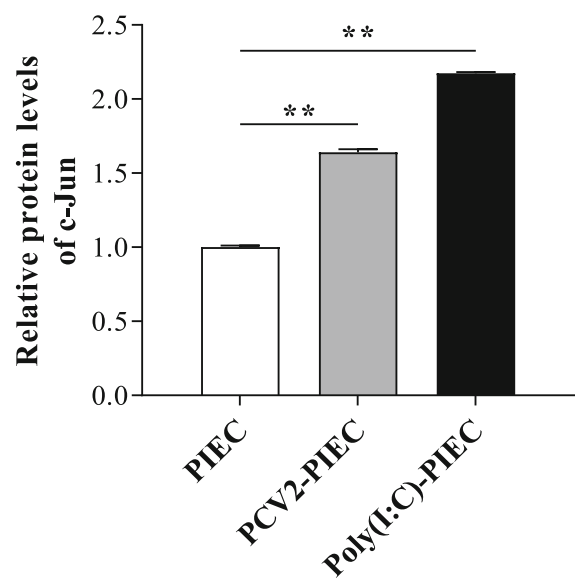

Fig. 5 The relative expression levels of key proteins in JNK signaling pathway. PIECs were infected with PCV2 (MOI =0.5) for $1 \mathrm{~h}$ and then cultured for 12 and $24 \mathrm{~h}$. The c-Jun mRNA expression was assessed by qPCR at two time points (a). Quantitative analyses of the immunoblot data of JNK (b) and c-Jun (c) was performed at $24 \mathrm{~h}$. The uninfected PIEC was used as a negative control and Poly(l:C) treatment was used as a positive control. Data are results of three independent experiments and presented as the mean and standard deviation (error bars) for each group. ${ }^{*}, P<0.05 .^{* *}, P<0.01$

its downstream signal will also be blocked [35, 36]. In this study, we confirmed that PCV2 could activate the adapter protein MAVS in PIECs. siRNA (siRIG-I, siMDA-5, siMAVS) transfection experiments further confirmed the roles of these signaling pathway above in the production of endothelial-derived IL-8 in PIEC after PCV2 infection. Taken together, PCV2 could activate the signaling pathway of RIG-I/MDA-5/MAVS in PIECs and therefore induced the production of endothelialderived IL-8.

Based on the previous results [9] and microarray results (unpublished data), we chose to investigate whether NF- $\mathrm{kB}$ and JNK signaling pathway were the key downstream pathway in this process. The results demonstrated that PCV2 infection could activate JNK but not NF-kB signaling pathway in PIECs. It indicated that
PCV2 could activate JNK signaling pathway to upregulate the production of endothelial-derived IL-8 in PIECs, which was different from the mechanism of monocytederived IL-8 production in downstream pathway.

\section{Conclusions}

Our study demonstrated that PCV2 could upregulate the production of endothelial-derived IL-8 via RIG-I/MDA5/MAVS/JNK signaling pathway in PIECs (Fig. 9). It elucidated the mechanism of endothelial-derived IL-8 production in PCV2 infected endothelial cells, which was different from the mechanism of monocyte-derived IL-8 production. Our study provides an insight into the further study of endothelial dysfunction and vascular system disorder caused by PCV2. 


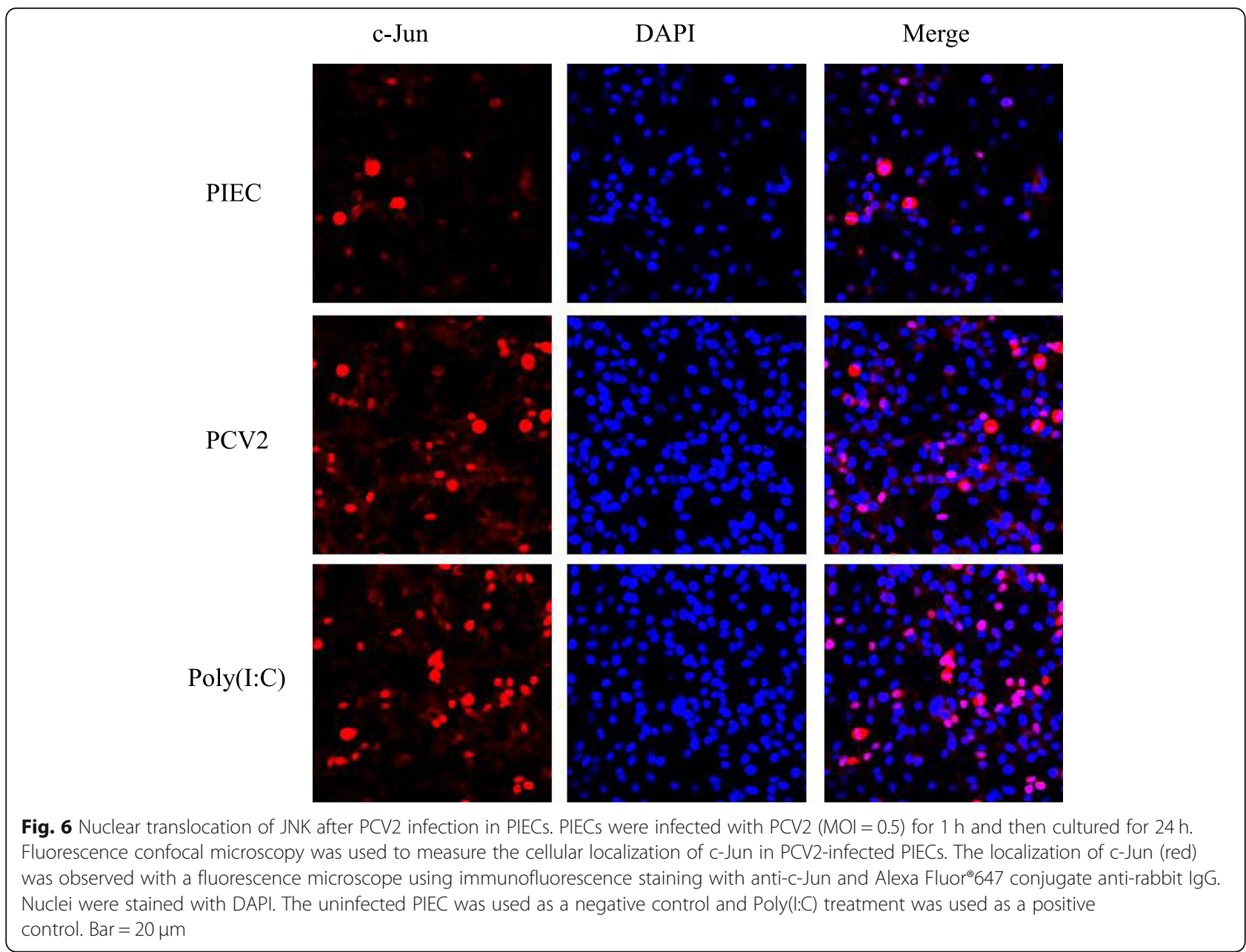

\section{Methods}

\section{Cells and virus}

Porcine iliac arterial endothelial cell (PIEC) (Cat. No. GN015) was purchased from the Cell Resource Center of the Shanghai Institute of Biological Sciences (Shanghai, China). The cells were cultured in RPMI 1640 medium (GIBCO, Grand Island, NY, USA) supplemented with 10\% fetal bovine serum (FBS) (BI, Kibbutz Beit, Israel), and incubated in an atmosphere of $5 \% \mathrm{CO}_{2}$ at $37^{\circ} \mathrm{C}$ (Thermo Fisher Scientific, Waltham, MA, USA). The PCV2 (PCV2SD/2008, GenBank accession number: GQ174519; it was isolated and identified by Animal Infectious Disease Laboratory of Hebei Agricultural University) stock was prepared in PK-15 cells with a titer of $10^{5.5} \mathrm{TCID}_{50} / \mathrm{ml}$.

\section{Extraction of total RNA and quantitative PCR}

PCV2 (MOI $=0.5)$ was used to infect $70 \%$ confluent PIECs in 6-well plate $\left(5 \times 10^{5}\right.$ cells/well). Cells were incubated for $1 \mathrm{~h}$ in an atmosphere of $5 \% \mathrm{CO}_{2}$ at $37^{\circ} \mathrm{C}$, and RPMI1640 supplemented with 10\% FBS was then added to infected cells. The experiment was performed with the control group (PIECs), the positive control group (Poly(I:C)-PIECs) and the infection group (PCV2PIECs). Cell samples were harvested with Trizol (Invitrogen, Carlsbad, CA, USA) at 12 and $24 \mathrm{hpi}$. Total RNA was extracted according to the instructions of the RNA extraction kit (Aidlab, Beijing, China), and the extracted RNA was reverse transcribed to synthesize cDNA according to the reverse transcription kit (Cwbio, Beijing, China). The mRNA expression of each molecule (RIG-I, MDA-5, MAVS, I $\mathrm{B} \alpha, \mathrm{c}-J u n$, endothelial-derived IL-8) was detected by qPCR. The reactions were performed in triplicate using SYBR Green Real-time PCR Master Mix (TOYOBO, Osaka, Japan) in the Mx3005P Detection System (Genetimes, Shanghai, China). The total reaction system was $20 \mu \mathrm{l}$ and contained the following: SYBR $^{\circ}$ Green Real-time PCR Master Mix $(10 \mu \mathrm{l}), 25 \mathrm{pmol} / \mu \mathrm{l}$ upstream and downstream primers (each for $0.2 \mu \mathrm{l}$ ), template DNA $(1.0 \mu \mathrm{l})$, and water $(8.6 \mu \mathrm{l})$. The conditions were as follows: $95^{\circ} \mathrm{C}$ for $5 \mathrm{~min}$, followed by $40 \mathrm{cy}$ cles of $95^{\circ} \mathrm{C}$ for $40 \mathrm{~s}, 56^{\circ} \mathrm{C}$ for $30 \mathrm{~s}$, and $72{ }^{\circ} \mathrm{C}$ for $30 \mathrm{~s}$. Water was used to replace template DNA in the negative control. All results were analyzed using MxPro Software. Primer sequences for qPCR are listed in Table 1. 


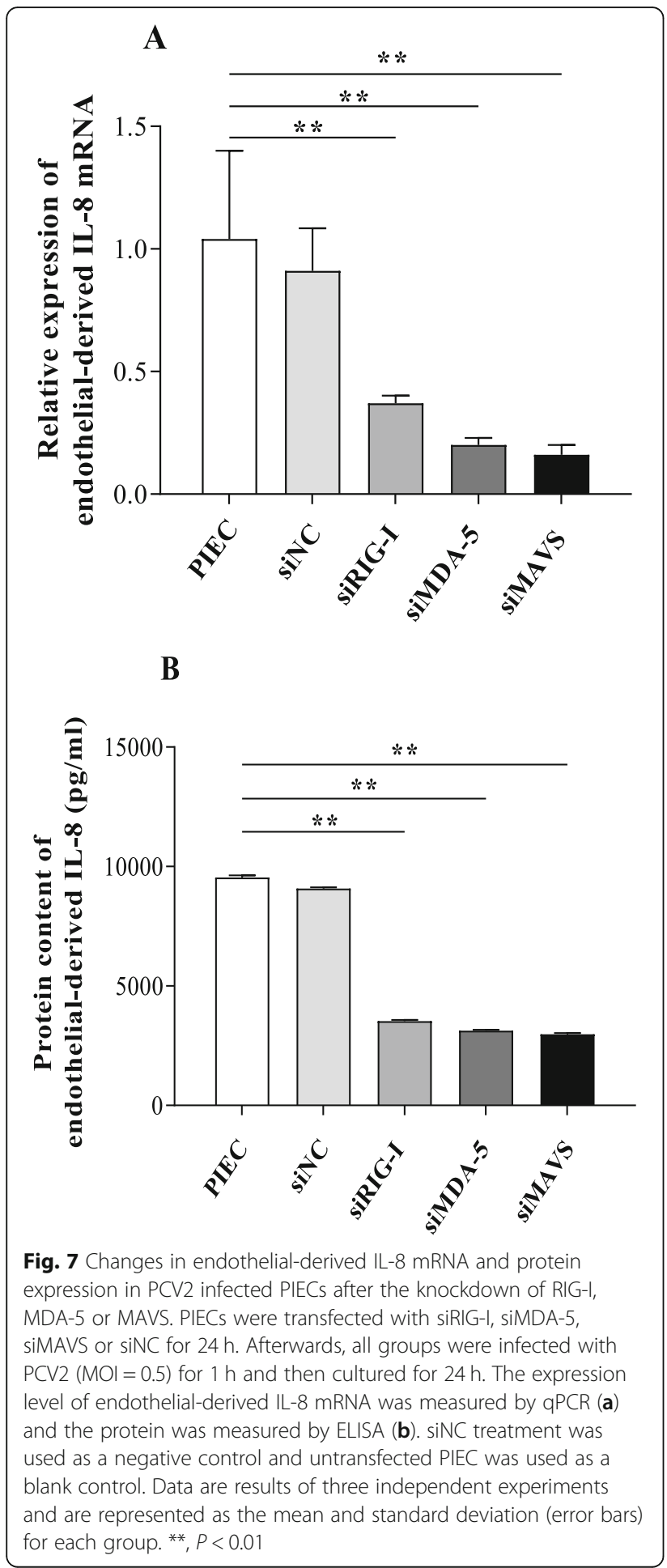

\section{Reagents and antibodies}

Poly(I:C) (InvivoGen, San Diego, CA, USA) was used for the positive control. All antibodies used for Western blot, such as primary antibodies (RIG-I, MDA-5, MAVS, IкB $\alpha, \mathrm{p} 65$, p-p65, JNK, c-Jun, $\beta$-actin), HRP-conjugated anti-mouse secondary antibody and HRP-conjugated

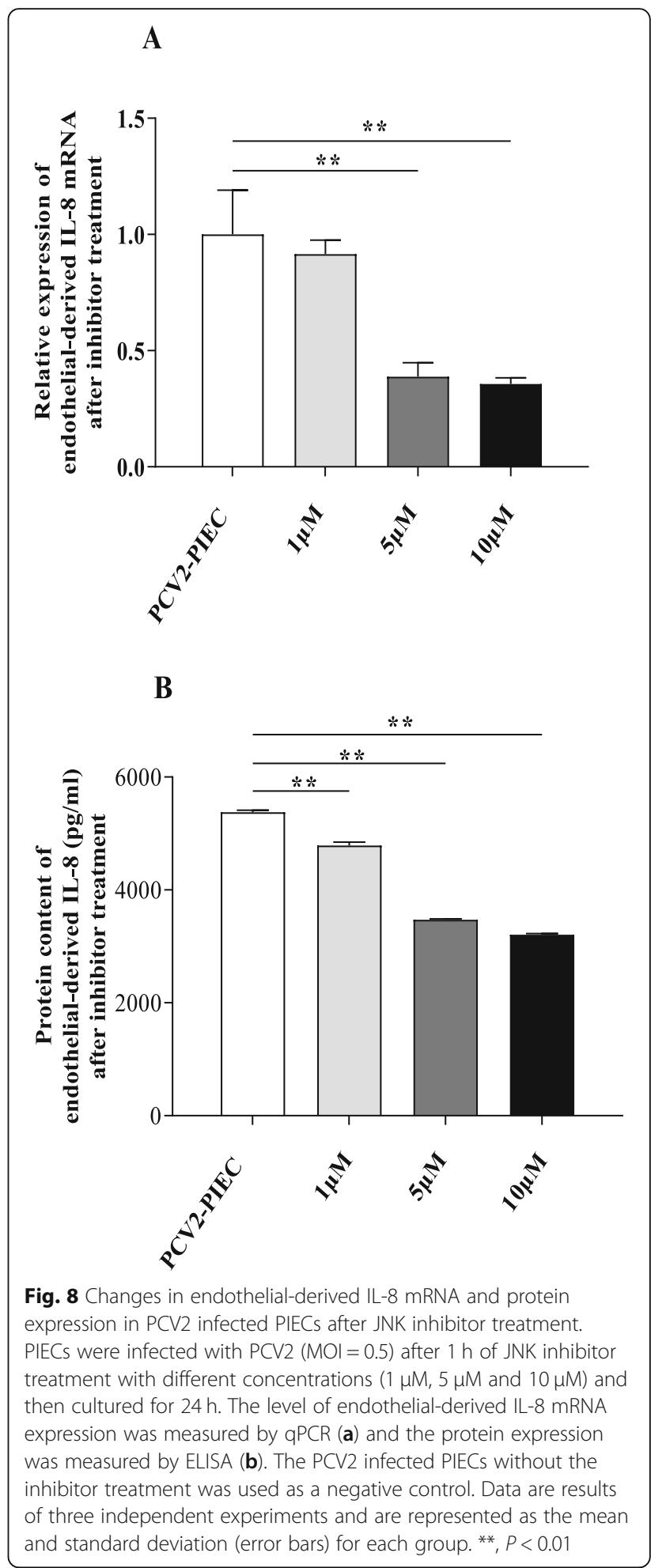

anti-rabbit secondary antibody were purchased from Cell Signaling Technology (CST, Danvers, MA, USA). Alexa Fluor ${ }^{\circ} 647$ conjugated anti-mouse IgG (CST, Danvers, MA, USA) and Alexa Fluor 647 conjugated anti-rabbit IgG (Beyotime, Shanghai, China) were used for the 


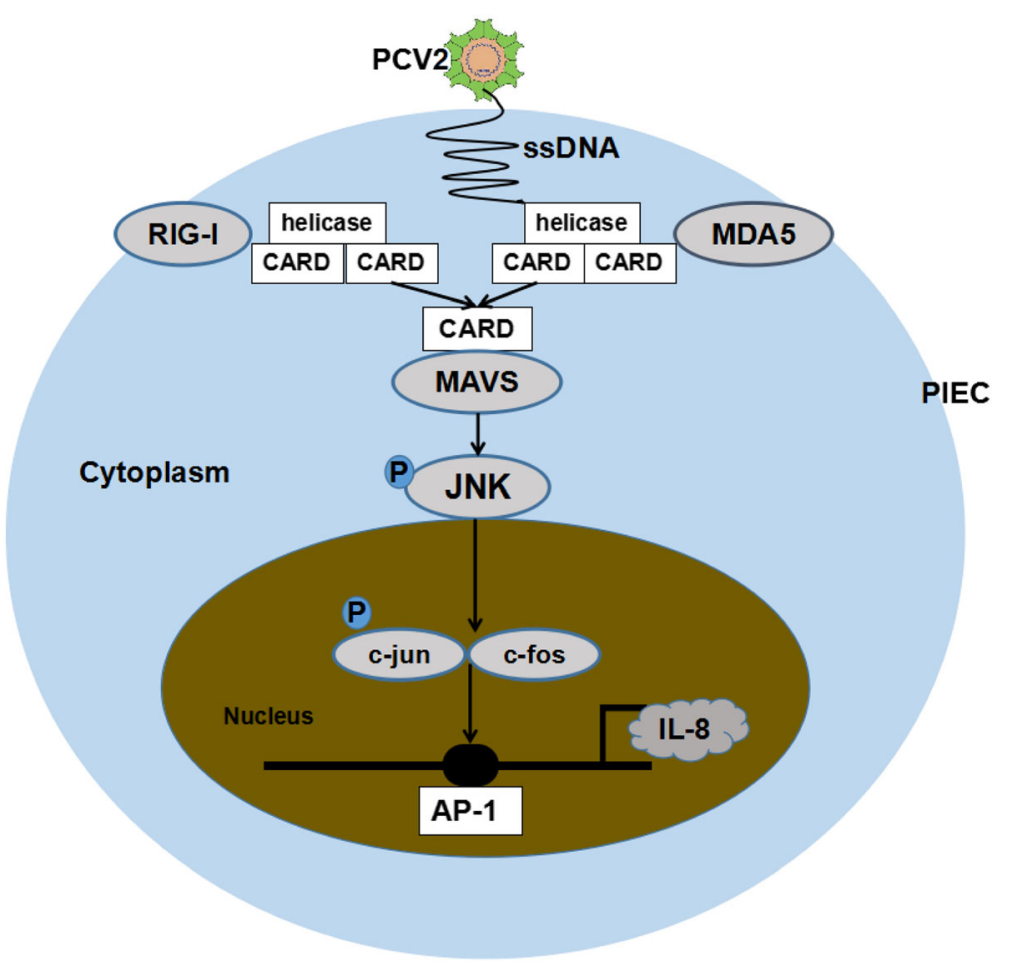

Fig. 9 Model of endothelial-derived IL-8 production induced by PCV2 in PIECs. Identification of PCV2 by RIG-I and MDA-5 activated a cascade of changes that led to the upregulation of MAVS and then stimulated the nuclei accumulation of JNK. As a result, endothelial-derived IL-8 was apparently upregulated. Knockdown of RIG-I, MDA-5 or MAVS using siRNA resulted in the negative modulation of endothelial-derived IL-8 secretion. Similar results were also obtained by the JNK inhibitor treatment. It shows that PCV2 can upregulate the production of endothelialderived IL-8 in PIECs via the RIG-I/MDA-5/MAVS/JNK signaling pathway

Table 1 Primers used for qPCR

\begin{tabular}{|c|c|c|c|c|}
\hline Genes Source/ accession No. & Accession number & Primer sequence $\left(5^{\prime}-3^{\prime}\right)$ & $\begin{array}{l}\text { Annealing temperature } \\
\left({ }^{\circ} \mathrm{C}\right)\end{array}$ & Products (bp) \\
\hline \multirow[t]{2}{*}{ RIG-I } & NM_213804.2 & For: TCTGGAGCAACGTCTGACAC & 56 & 166 \\
\hline & & Rev: GTTTGCTGGTGTTGTGGCAT & & \\
\hline \multirow[t]{2}{*}{ MDA-5 } & NM_001100194.1 & For: TGGACACAGCAGTGAGTTCAAGC & 51 & 105 \\
\hline & & Rev: GCCACCGTGGTAGCGATAAGC & & \\
\hline \multirow[t]{2}{*}{ MAVS } & XM_005672763.1 & For: GGCATCAGAAGCAGGACACAGAAC & 59 & 177 \\
\hline & & Rev: CAGTGGAGGAGGAGGCAGTAGAC & & \\
\hline \multirow[t]{2}{*}{ IkBa } & NM_001005150.1 & For: CCAACCAGCCAGAAATCGCT & 58 & 168 \\
\hline & & Rev: GCAGAATGGAGTGGAGGTGC & & \\
\hline \multirow[t]{2}{*}{ c-Jun } & NM_213880.1 & For: GCATCGCTGCCTCCAAGT & 56 & 224 \\
\hline & & Rev: CCCAACAGTCTCGCCTCAAA & & \\
\hline \multirow[t]{2}{*}{ IL-8 } & NM_213867 & For: TCCTGCTITCTGCAGCTCTC & 59 & 100 \\
\hline & & Rev: GGGTGGAAAGGTGTGGAATG & & \\
\hline \multirow[t]{2}{*}{$\beta$-actin } & XM_003357928 & For: TCATCACCATCGGCAACT & 58 & 133 \\
\hline & & Rev: TTCCTGATGTCCACGTCGC & & \\
\hline
\end{tabular}


fluorescence confocal microscopy. JNK inhibitor SP600125 was purchased from Beyotime, Shanghai, China and Protein Marker 26616 was purchased from Thermo Fisher Scientific, Waltham, MA, USA.

\section{Western blot analysis}

$70 \%$ confluent PIECs in a 6-well plate was infected with PCV2 (MOI $=0.5)$ with Poly $(\mathrm{I}: \mathrm{C})(5 \mu \mathrm{g} / \mathrm{ml})$ for $1 \mathrm{~h}$ in an atmosphere of $5 \% \mathrm{CO}_{2}$ at $37^{\circ} \mathrm{C}$. The cells were further incubated for $24 \mathrm{~h}$ in RPMI1640 supplemented with $10 \%$ FBS. Total proteins were extracted from the collected cells according to the manufacturer instructions of total protein extraction kit (Keygen, Nanjing, China) and quantified by BCA protein assay kit (Cwbio, Beijing, China). Quantitative protein was subjected to SDSPAGE and then transferred onto a polyvinylidene difluoride (PVDF) membrane. The membrane was further blocked with Tris Buffer Solution Tween-20 (TBST) containing 5\% BSA for $2 \mathrm{~h}$ and then incubated overnight in a 1:2000 dilution of primary antibody at $4{ }^{\circ} \mathrm{C}$ with gentle shaking. After washed four times in TBST, the membrane was blotted with the second antibody (1: 5000) for $1 \mathrm{~h}$. Actin was used as the internal reference. The blot was visualized with Omega Aplegen scanner (Aplegen, San Francisco, CA, USA). The gray matter volume of protein was quantified by importing the images into an ImageJ analysis software. The original blots can be referred in the Additional file 1.

\section{Fluorescence confocal microscopy}

The cells were treated in the same manner as Western blot analysis. At $24 \mathrm{hpi}$, the cells were digested with $0.25 \%$ trypsin. All cells were centrifuged and the supernatant was discarded. The cells were suspended in $200 \mu \mathrm{l}$ of RPMI1640 supplemented with 10\% FBS, and then dripped into a confocal chamber treated with polylysine. After adhering for $4 \mathrm{~h}$, the supernatant was discarded, PIECs were fixed with $2 \%$ paraformaldehyde for $15 \mathrm{~min}$ at room temperature. After washed three times with phosphate-buffered saline (PBS), they were blocked with blocking solution for $1 \mathrm{~h}$. Then, the diluted primary antibody (p65 1:800, c-Jun 1:400) was added and incubated overnight at $4{ }^{\circ} \mathrm{C}$. The diluted secondary antibody (1:500) was added in the dark and incubated at room temperature for $1 \mathrm{~h}$. The nucleus was stained with DAPI solution at $37^{\circ} \mathrm{C}$ for $20 \mathrm{~min}$. Anti-fluorescence attenuating seals were added dropwise protected from light at $4^{\circ} \mathrm{C}$. The cells were observed with a laser scanning confocal microscopy (Olympus FV100, Hamburg, Germany).

\section{siRNA interference}

$5 \mu \mathrm{l}$ of Lipofectamine 2000 (Invitrogen, Carlsbad, CA, USA) and $150 \mathrm{pmol}$ of siRNA (siRIG-I, siMDA-5, siMAVS) (Gene Pharma, Shanghai, China) were added into 6-well plates with pre-plated PIECs in serum-free RPMI1640. After $6 \mathrm{~h}$, the serum-free medium was replaced by RPMI1640 supplemented with 10\% FBS. For optimal knockdown, the transfection efficiency of siRIGI, siMDA-5, and siMAVS were detected by qPCR after $24 \mathrm{~h}$ and Western blot after $48 \mathrm{~h}$ (Additional file 2). The siRNA primers were listed in Table 2.

\section{Inhibitor treatment}

PIECs were inoculated into 6-well plates. When the cells covered $50-70 \%$ of the surface, they were treated with JNK inhibitor SP600125. The same dose of dimethyl sulfoxide (DMSO) was used as the control (The final concentration of DMSO was less than $0.1 \%$ ). After $1 \mathrm{~h}$ of treatment, the cells were washed with PBS and then infected with PCV2 $(\mathrm{MOI}=0.5)$ for $1 \mathrm{~h}$. The cells and supernatants were sampled after $24 \mathrm{~h}$. The expression of endothelial-derived IL-8 was detected by qPCR and ELISA.

\section{ELISA}

The expression of endothelial-derived IL-8 in the supernatant of each group was determined according to the manufacturer instructions of porcine IL-8 ELISA kit (CUSABIO, Wuhan, China). The OD value was read at $490 \mathrm{~nm}$ using a microplate reader (BioTek, Winooski, VT, USA). Standard curves were obtained according to Curve Expert software using the dilutions of a sample

Table 2 siRNA primer sequences used for cell transfection

\begin{tabular}{lll}
\hline Genes Source/ accession No. & Accession number & Primer sequence (5'-3') \\
\hline siRIG-I & EU126659.1 & For: CACCAGCAAACAGCAUCCUUAUAAU \\
siMDA-5 & & Rev: AUUAUAAGGAUGCUGUUUGCUGGUG \\
& EU006039.1 & For: GCAGACGAAGUUUGCUGACUAUCAA \\
siMAVS & & Rev: UUGAUAGUCAGCAAACUUCGUCUGC \\
& AB287431.1 & For: AUGGAUAGCCAGCCUUUCUTT \\
siNC & & Rev: AGAAAGGCUGGCUAUCCAUCC \\
& & For: GCGCGCUUUGUAGGAUUCGTT \\
& & Rev: CGAAUCCUACAAAGCGCGCTT
\end{tabular}


from the kit as the template. Concentration of the samples in the different groups was calculated according to the standard curve.

\section{Statistical analysis}

We performed all statistical analyses using the SPSS Statistics 17 (IBM Corporation). The results are expressed as the mean \pm standard deviation (SD). Differences between the experimental groups and the control groups were analyzed using ANOVA followed by the Duncan's multiple range test for multiple comparisons. $P<0.05$ was considered to be statistically different and was denoted by *. $P<0.01$ was considered to be significantly different and was denoted by **. $P<0.001$ was considered to be extremely significantly different and was denoted by $* * \%$. Unless indicated otherwise, the experiments were performed in triplicate $(n=3)$.

\section{Supplementary information}

Supplementary information accompanies this paper at https://doi.org/10 1186/s12917-020-02486-1.

Additional file 1. The original blots for the figures. For our gel data, the target proteins analyzed by western blot were transferred from SDS-PAGE and the PVDF membrane would be sliced into different strips according to their protein size identified with the loading marker. Then the panel of antibodies targeting these proteins were used for western blot analysis. Our SOP for processing the gel data only collected the pictures with target protein regions instead of the whole gel, so here are the original gels for the data we presented in the manuscript.

Additional file 2 The transfection efficiency of siRIG-I, siMDA-5 and siMAVS. PIECs were transfected with siRIG-I, siMDA-5, siMAVS or siNC for $24 \mathrm{~h}$. Afterwards, all groups were infected with PCV2 $(\mathrm{MOI}=0.5)$ for $1 \mathrm{~h}$ and then cultured for $24 \mathrm{~h}$. The result of qPCR showed the mRNA level of RIG-I, MDA-5 or MAVS at $24 \mathrm{~h}$ (A). The result of Western blot showed the protein level of RIG-I (B), MDA-5 (C) or MAVS (D) at $48 \mathrm{~h}$. siNC treatment was used as a negative control and untransfected PIEC was used as a blank control. Data are results of three independent experiments and are represented as the mean and standard deviation (error bars) for each group. ${ }^{* *}, P<0.01$.

\section{Abbreviations}

PCVD: Porcine circovirus disease; PCV2: Porcine circovirus type 2; PIECs: Porcine iliac artery endothelial cells; PMWS: Postweaning multisystemic wasting syndrome; RLRs: Retinoic acid-induced gene I-like receptors; RIGI: Retinoic acid-inducible gene I; MDA-5: Melanoma differentiation-associated gene-5; PRRs: Pattern recognition receptors; Poly(l:C): Polyriboinsinepolyribocyaidylic acid; MAVS: Mitochondrial antiviral signaling protein; Hpi: Hours post-infection; FBS: Fetal bovine serum; PVDF: Polyvinylidene difluoride; TBST: Tris buffer solution tween-20; PBS: Phosphate-buffered saline; DMSO: Dimethyl sulfoxide; SD: Standard deviation

\section{Acknowledgments}

We would like to thank Mr. Xu (Department of Hematology, Xiyuan Hospital of China Academy of Chinese Medical Sciences) for his help with the statistical analysis.

\section{Authors' contributions}

FYS conceived of the study and drafted the manuscript. FYS, QML, SYL and FYL carried out the experiments. JFW, DFC and XLH revised the manuscript. $\mathrm{SHZ}$ performed the statistical analysis. $\mathrm{YHZ}$ and $\mathrm{HRL}$ designed the study and critically revised the manuscript. The authors read and approved the final manuscript.

\section{Funding}

This research was funded by the National Natural Science Foundation of China [grant number, 31472174], Beijing Natural Science Foundation \& Key Project of Science and Technology Plan of Beijing Education Commission [grant number, KZ201910020021], and Beijing Innovation Consortium of Swine Research System (BAIC02). These funding institutions only provided monetary support and were not involved in the design of the research, the collection and analysis of data, nor writing of the manuscript or submission for publication.

\section{Availability of data and materials}

The datasets used and/or analysed during the current study are available from the corresponding author on reasonable request.

Ethics approval and consent to participate

Not applicable.

\section{Consent for publication}

Not applicable.

\section{Competing interests}

The authors declare no conflict of interest.

\section{Author details}

${ }^{1}$ College of Animal Science and Technology, Beijing University of Agriculture, No. 7 Beinong Road, Beijing 102206, Changping District, China. ${ }^{2}$ Beijing Key Laboratory of TCVM, Beijing University of Agriculture, No. 7 Beinong Road, Beijing 102206, Changping District, China.

Received: 20 January 2020 Accepted: 22 July 2020

Published online: 29 July 2020

\section{References}

1. Kim J, Chung HK, Chae C. Association of porcine circovirus 2 with porcine respiratory disease complex. Vet J. 2003;166(3):251-6.

2. Marks FS, Reck J Jr, Almeida LL, Berger M, Corrêa AM, Driemeier D, et al. Porcine circovirus 2 ( $P C$ V2) induces a procoagulant state in naturally infected swine and in cultured endothelial cells. Vet Microbiol. 2010;141(1-2):22-30.

3. Marks FS, Almeida LL, Driemeier D, Canal C, Barcellos DE, Guimarães JA, et al. Porcine circovirus 2 (PCV2) increases the expression of endothelial adhesion/junction molecules. Braz J Microbiol. 2016;47(4):870-5.

4. Yang N, Qiao J, Liu S, Zou Z, Zhu L, Liu X, et al. Change in the immune function of porcine iliac artery endothelial cells infected with porcine circovirus type 2 and its inhibition on monocyte derived dendritic cells maturation. PLoS One. 2017;12(10):e0186775.

5. Gimbrone MA Jr, Obin MS, Brock AF, Luis EA, Hass PE, Hébert CA, et al. Endothelial interleukin-8: a novel inhibitor of leukocyte-endothelial interactions. Science. 1989:246(4937):1601-3.

6. Van Damme J, Van Beeumen J, Conings R, Decock B, Billiau A. Purification of granulocyte chemotactic peptide/interleukin-8 reveals N-terminal sequence heterogeneity similar to that of beta-thromboglobulin. Eur J Biochem. 1989;181(2):337-44.

7. Liu S, Li Q, Qiao J, Wang J, Cui D, Gu K, et al. Endothelial IL-8 induced by porcine circovirus type 2 affects dendritic cell maturation and antigenpresenting function. Virol J. 2019;16(1):154.

8. Galván Morales MÁ, Cabello Gutiérrez C, Mejía Nepomuceno F, Valle Peralta L, Valencia Maqueda E, Manjarrez Zavala ME. Parainfluenza virus type 1 induces epithelial IL-8 production via p38-MAPK signalling. J Immunol Res. 2014;2014:515984.

9. Qin Y, Li H, Qiao J. TLR2/MyD88/NF-KB signaling pathway regulates IL-8 production in porcine alveolar macrophages infected with porcine circovirus 2. J Gen Virol. 2016;97(2):445-52.

10. Barral PM, Sarkar D, Su ZZ, Barber GN, DeSalle R, Racaniello VR, et al. Functions of the cytoplasmic RNA sensors RIG-I and MDA-5: key regulators of innate immunity. Pharmacol Ther. 2009;124(2):219-34.

11. Loo YM, Gale M Jr. Immune signaling by RIG-I-like receptors. Immunity. 2011;34(5):680-92.

12. Li J, Kartha S, lasvovskaia S, Tan A, Bhat RK, Manaligod JM, et al. Regulation of human airway epithelial cell IL-8 expression by MAP kinases. Am J Physiol Lung Cell Mol Physiol. 2002;283(4):L690-9.

13. Liu $Y$, Du $Y$, Wang $H$, Du L, Feng WH. Porcine reproductive and respiratory syndrome virus (PRRSV) up-regulates IL-8 expression through TAK-1/JNK/AP1 pathways. Virology. 2017;506:64-72. 
14. Wang L, Tang C, Cao H, Li K, Pang X, Zhong L, et al. Activation of IL-8 via PIJK Akt-dependent pathway is involved in leptin-mediated epithelial-mesenchymal transition in human breast cancer cells. Cancer Biol Ther. 2015;16(8):1220-30.

15. Huang $B$, Li J, Zhang X, Zhao Q, Lu M, Lv Y. RIG-I and MDA-5 signaling pathways contribute to IFN- $\beta$ production and viral replication in porcine circovirus virus type 2-infected PK-15 cells in vitro. Vet Microbiol. 2017;211:36-42.

16. Dong W, Lv H, Guo K, Wang T, Ouyang Y, Jin M, et al. Classical swine fever virus infection and its NS4A protein expression induce IL-8 production through MAVS signaling pathway in swine umbilical vein endothelial cells. Front Microbiol. 2018;8:2687.

17. Dong XY, Liu WJ, Zhao MQ, Wang JY, Pei JJ, Luo YW, et al. Classical swine fever virus triggers RIG-I and MDA-5 dependent signaling pathway to IRF-3 and NF-KB activation to promote secretion of interferon and inflammatory cytokines in porcine alveolar macrophages. Virol J. 2013;10:286.

18. Wörnle M, Sauter M, Kastenmüller K, Ribeiro A, Mussack T, Ladurner R, et al. Role of toll-like receptor 3, RIG-I, and MDA5 in the expression of mesothelial IL-8 induced by viral RNA. Appl Biochem Biotechnol. 2010;160(4):1179-87.

19. Sathe A, Reddy KV. TLR9 and RIG-I signaling in human endocervical epithelial cells modulates inflammatory responses of macrophages and dendritic cells in vitro. PLoS One. 2014;9(1):e83882.

20. Kato H, Takeuchi O, Sato S, Yoneyama M, Yamamoto M, Matsui K, et al. Reis e Sousa C, Matsuura Y, Fujita T, Akira S. differential roles of MDA5 and RIG-I helicases in the recognition of RNA viruses. Nature. 2006;441(7089):101-5.

21. Yoneyama M, Kikuchi M, Natsukawa T, Shinobu N, Imaizumi T, Miyagishi M, et al. The RNA helicase RIG-I has an essential function in double-stranded RNA-induced innate antiviral responses. Nat Immunol. 2004;5(7):730-7.

22. Ablasser A, Bauernfeind F, Hartmann G, Latz E, Fitzgerald KA, Hornung V. RIG--dependent sensing of poly (dA:dT) through the induction of an RNA polymerase III-transcribed RNA intermediate. Nat Immunol. 2009;10(10):1065-72.

23. Kumagai Y, Takeuchi O, Akira S. Pathogen recognition by innate receptors. $J$ Infect Chemother. 2008;14(2):86-92.

24. Chang $T H$, Liao CL, Lin YL. Flavivirus induces interferon-beta gene expression through a pathway involving RIG-I-dependent IRF-3 and PI3Kdependent NF-kappaB activation. Microbes Infect. 2006;8(1):157-71.

25. Faul EJ, Wanjalla CN, Suthar MS, Gale M, Wirblich C, Schnell MJ. Rabies virus infection induces type I interferon production in an IPS-1 dependent manner while dendritic cell activation relies on IFNAR signaling. PLoS Pathog. 2010;6(7):e1001016.

26. Roth-Cross JK, Bender SJ, Weiss SR. Murine coronavirus mouse hepatitis virus is recognized by MDA5 and induces type I interferon in brain macrophages/microglia. J Virol. 2008;82(20):9829-38.

27. Ikegame S, Takeda M, Ohno S, Nakatsu Y, Nakanishi Y, Yanagi Y. Both RIG-I and MDA5 RNA helicases contribute to the induction of alpha/beta interferon in measles virus-infected human cells. J Virol. 2010;84(1):372-9.

28. Fredericksen BL, Keller BC, Fornek J, Katze MG, Gale M Jr. Establishment and maintenance of the innate antiviral response to West Nile virus involves both RIG-I and MDA5 signaling through IPS-1. J Virol. 2008:82(2):609-16.

29. Dvorak CMT, Puvanendiran S, Murtaugh MP. Porcine circovirus 2 infection induces IFN 3 expression through increased expression of genes involved in RIG-I and IRF7 signaling pathways. Virus Res. 2018;253:38-47.

30. Sun Q, Sun L, Liu HH, Chen X, Seth RB, Forman J, et al. The specific and essential role of MAVS in antiviral innate immune responses. Immunity. 2006;24(5):633-42.

31. Kawai T, Takahashi K, Sato S, Coban C, Kumar H, Kato H, et al. IPS-1, an adaptor triggering RIG-I and MDA5-mediated type I interferon induction. Nat Immunol. 2005;6(10):981-8

32. Seth RB, Sun L, Ea CK, Chen ZJ. Identification and characterization of MAVS, a mitochondrial antiviral signaling protein that activates NF-kappaB and IRF 3. Cell. 2005;122(5):669-82.

33. $X u L G$, Wang $Y Y$, Han KJ, Li LY, Zhai Z, Shu HB. VISA is an adapter protein required for virus-triggered IFN-beta signaling. Mol Cell. 2005;19(6):727-40.

34. Liu S, Chen J, Cai X, Wu J, Chen X, Wu YT, et al. MAVS recruits multiple ubiquitin E3 ligases to activate antiviral signaling cascades. Elife. 2013;2:e00785.

35. Mukherjee A, Morosky SA, Delorme-Axford E, Dybdahl-Sissoko N, Oberste MS, Wang T, et al. The coxsackievirus B 3C protease cleaves MAVS and TRIF to attenuate host type I interferon and apoptotic signaling. PLoS Pathog. 2011;7(3):e1001311.

36. Meylan E, Curran J, Hofmann K, Moradpour D, Binder M, Bartenschlager R, et al. Cardif is an adaptor protein in the RIG-I antiviral pathway and is targeted by hepatitis C virus. Nature. 2005;437(7062):1167-72.

\section{Publisher's Note}

Springer Nature remains neutral with regard to jurisdictional claims in published maps and institutional affiliations.

\section{Ready to submit your research? Choose BMC and benefit from}

- fast, convenient online submission

- thorough peer review by experienced researchers in your field

- rapid publication on acceptance

- support for research data, including large and complex data types

- gold Open Access which fosters wider collaboration and increased citations

- maximum visibility for your research: over $100 \mathrm{M}$ website views per year

At BMC, research is always in progress.

Learn more biomedcentral.com/submissions 